\title{
KUALITAS PRODUK TERHADAP KEPUASAN PELANGGAN DI KOPI BOX WANEA MANADO
}

\section{Mac Donald Walangitan}

Fakultas Ekonomi dan Bisnis Universitas Sam Ratulangi

\author{
A R T I C LE I N FO
}

Keywords : products quality,consumer satisfaction

Kata Kunci: kualitas produk, kepuasan

pelanggan

\begin{abstract}
Coffee Box Wanea, is a type of business that serves trending type of coffee for consumer. To improving customer satisfaction of Coffee Box certainly needed a quality product. Consumer satisfaction is a response to consumer behavior evaluation form after purchasing the goods or services he feels (product performance) compared with consumer expectations. The purpose of this study was to determine the effect of product quality to customer satisfaction in Coffee Box Wanea Manado. This type of research in this study is a type of associative research using data analysis techniques simple linear regression. Collecting data using a questionnaire distributed to 100 respondents. The results showed that the significant effect on the Product Quality Customer Satisfaction At Coffee Box Wanea Manado
\end{abstract}

Abstrak : Kopi Box Wanea, merupakan jenis usaha yang menyajikan berbagai jenis kopi bagi pelangganya. Untuk meningkatkan kepuasan dari Pelanggan Kopi Box tentunya diperlukan produk yang berkualitas. Kepuasan konsumen merupakan suatu tanggapan perilaku konsumen berupa evaluasi purna beli terhadap suatu barang atau jasa yang dirasakannya (kinerja produk) dibandingkan dengan harapan konsumen. Tujuan penelitian ini adalah untuk mengetahui pengaruh kualitas produk terhadap kepuasan pelanggan di Kopi Box Wanea Manado. Jenis penelitian yang dalam penelitian ini adalah jenis penelitian assosiatif dengan menggunakan teknik analisis data regresi linier sederhana. Pengumpulan data menggunakan kuisioner yang dibagikan kepada 100 orang responden. Hasil penelitian menunjukkan bahwa Kualitas Produk berpengaruh signifikan terhadap Kepuasan Pelanggan Di Kopi Box Wanea Manado/ 


\section{PENDAHULUAN}

\section{Latar Belakang}

Perkembangan usaha di Indonesia akhir-akhir ini berkembang sangat pesat dan cepat. Hal ini terlihat semakin banyak bermunculan jenis usaha di Indonesia. Hal ini mengakibatkan tingkat persaingan di dunia usaha juga semakin ketat, sehingga masing-masing jenis usaha berlomba-lomba untuk persaingan tersebut. Untuk memenangkan persaingan di dunia usaha, masing-masing perusahaan berusaha menciptakan suatu konsep pemasaran yang mampu untuk menarik konsumen untuk membeli produk yang ditawarkan.

Kegiatan pemasaran produk menjadi salah satu faktor suatu perusahaan dalam proses penyampaian produk kepada pelanggan serta pencapaian tujuan perusahaan berupa penjualan produk yang optimal. Sebelum meluncurkan produknya perusahaan harus mampu melihat atau mengetahui apa yang dibutuhkan oleh konsumen. Sehingga sudah sewajarnya jika segala kegiatan perusahaan harus selalu dicurahkan untuk memenuhi kebutuhan konsumen dan kemudian konsumen akan memutuskan membeli produk tersebut. Dan pada akhirnya tujuan perusahaan yaitu memperoleh laba akan tercapai.

Salah satu usaha yang sangat trend dikalangan anak muda maupun orang dewasa adalah usaha café dengan menyajikan kopi. Melimpahnya potensi kopi di berbagai penjuru nusantara, ternyata cukup memudahkan para pelaku usaha untuk bisa memenuhi kebutuhan bahan baku kopi bagi perkembangan bisnis yang sedang mereka rintis. Tercatat sebagai salah satu negara penghasil kopi di kelas dunia, tentunya para pelaku usaha bisa memanfaatkan kekayaan alam Indonesia tanpa harus mengimpor bahan baku kopi dari pasar luar negeri. Kopi Box Wanea, merupakan jenis usaha yang menyajikan bebagai jenis kopi bagi pelangganya. Dengan berbagai macam alat untuk mengolah setiap jenis kopi mejadikan Kopi Box bukan hanya sebagai tempat menikmati kopi, namum tempat untuk melihat seni membuat kopi. Berbagai jenis Kopi yang dijual merupakan komoditas asli Indonesia serta ada juga kopi dari luar negeri seperti kopi Vietnam dan kopi Hongkong.

Produk merupakan segala sesuatu yang dapat ditawarkan kepasar untuk mendapatkan perhatian, dibeli, digunakan, atau dikonsumsi yang dapat memuaskan keinginan atau kebutuhan. Secara konseptual produk adalah pemahaman subyektif dari produsen atas sesuatu yang bisa ditawarkan sebagai usaha untuk mencapai tujuan organisasi melalui pemenuhan kebutuhan dan kegiatan konsumen, sesuai dengan kompetensi dan kapasitas organisasi serta daya beli pasar. Untuk meningkatkan kepuasan dari Pelanggan Kopi Box tentunya diperlukan produk yang berkualitas. Kepuasan konsumen merupakan suatu tanggapan perilaku konsumen berupa evaluasi purna beli terhadap suatu barang atau jasa yang dirasakannya (kinerja produk) dibandingkan dengan harapan konsumen.

\section{Tujuan Penelitian}

Tujuan penelitian ini untuk mengetahui pengaruh kualitas produk terhadap kepuasan pelanggan di Kopi Box Wanea

\section{TINJAUAN PUSTAKA}

\section{Manajemen Pemasaran}

Pemasaran merupakan salah satu kegiatan penting yang perlu dilakukan perusahaan untuk meningkatkan usaha dan menjaga kelangsungan hidup perusahaan tersebut.Disamping kegiatan pemasaran perusahaan juga perlu mengkombinasikan fungsi-fungsi dan menggunakan keahlian mereka agar perusahaan berjalan dengan baik. Pemasaran adalah system keseluruhan dari kegiatan-kegiatan usaha yang ditujukan untuk merencanakan, menentukan harga, mempromosikan, dan mendistribusikan barang dan jasa yang dapat memuaskan kebutuhan baik kepada pembeli yang ada maupun pembeli potensial (Swasta dan Handoko, 2012). Manajemen Pemasaran adalah penganalisaan, perencanaan dan pengawasan program-program yang bertujuan menimbulkan pertukarandengan pasar yang dituju dengan maksud untuk mencapai tujuan perusahaan (swastha dan Handoko,2012)

\section{Kepuasan Pelanggan}

Kepuasan adalah perasaan senang atau kecewa seseorang yang muncul setelah membandingkan kinerja (hasil) produk yang dipikirkan terhadap kinerja (atau hasil) yang diharapkan. Jika kinerja berada di bawah harapan maka pelanggan tidak puas. Jika kinerja memenuhi harapan maka pelanggan puas. Menurut Lovelock dan Wirtz 163 
(2011:74) Kepuasan adalah suatu sikap yang diputuskan berdasarkan pengalaman yang didapatkan. Kepuasan merupakan penilaian mengenai ciri atau keistimewaan produk atau jasa, atau produk itu sendiri, yang menyediakan tingkat kesenangan konsumen berkaitan dengan pemenuhan kebutuhan konsumsi konsumen.

\section{Kualitas Produk}

Menurut Kotler dan Armstrong (2012:283) kualitas produk adalah Kemampuan sebuah produk dalam memperagakan fungsiya, hal ini termasuk keseluruhan durabilitas, reliabilitas, ketepatan, kemudahan pengoperasian, dan reparasi produk, juga atribut produk lainnya Salah satu nilai utama yang diharapkan oleh pelanggan dari produsen adalah kualitas produk dan jasa yang tertinggi.

\section{Penelitian Terdahulu}

Widjoyo dan Semuel (2014) Perkembangan bisnis makanan di Indonesia yang semakin berkembang pesat juga menyebabkan meningkatnya persaingan. Sebagai salah satu restoran, Happy Garden harus memiliki keunggulan untuk mampu bersaing agar dapat bertahan dan memenangkan persaingan dalam bisnis makanan ini. Salah satu cara yang dapat digunakan untuk mencapai keunggulan tersebut adalah dengan menerapkan kualitas layanan dan kualitas produk yang tepat sehingga dapat meningkatkan kepuasan pelanggan dan menciptakan loyalitas konsumen. Penelitian ini bertujuan untuk menganalisa pengaruh dari kualitas layanan dan kualitas produk terhadap kepuasan pelanggan dan loyalitas konsumen di restoran Happy Garden Surabaya serta mengetahui faktor mana yang berpengaruh dominan di restoran tersebut. Dalam pengumpulan data, peneliti menyebarkan kuesioner kepada 160 responden yang merupakan konsumen dari Happy Garden Surabaya. Alat analisa yang digunakan untuk mengukur pengaruh Kualitas Layanan dan Kualitas Produk terhadap Kepuasan Pelanggan dan Loyalitas Konsumen adalah Structural Equation Model (SEM)

Hipotesis Penelitian

Diduga secara parsial kualitas produk berpengaruh terhadap keputusan pembelian di Kopi Box Wanea Manado.

\section{Kerangka Konseptual}

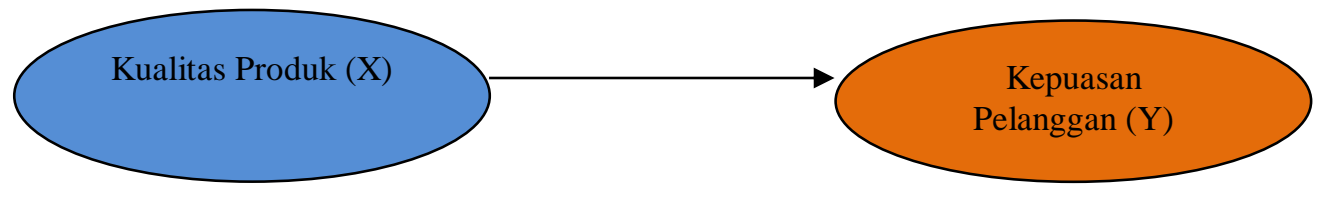

Gambar 1. Kerangka Penelitian

\section{METODE PENELITIAN}

\section{Jenis Penelitian}

Penelitian ini merupakan penelitian asosiatif yang merupakan penelitian yang mengkonfirmasi hubungan antar variable. Penelitian yang digunakan untuk meneliti pada populasi atau sampel tertentu, teknik pengambilan sampel pada umumnya dilakukan secara acak, pengumpulan data menggunakan instrument penelitian, analisis data bersifat kuantitatif/statistik dengan tujuan untuk menguji hipotesis yang telah ditetapkan (Sugiyono, 2012).

\section{Populasi dan Sampel}

Populasi dalam penelitian ini adalah seluruh pelanggan Kopi Box Wanea Manado. Jumlah Sampel dalam penelitian ini sebanyak 100 Responden. 


\section{Metode Analisis}

Metode analisa yang digunakan adalah uji asumsi klasik, uji valditas, uji reliabilitas, analisis regresi linear sederhana, dilengkapi pengujian hipotesis secara parsial dengan uji t.

\section{Analisa Regresi Linear Berganda}

Metode analisis ini dilakukan menggunakan analisis regresi linier barganda untuk memperhitungkan atau memperkirakan secara kuantitatif dari variabel-variabel yang digunakan, baik secara parsial maupun simultan yang berpengaruh terhadap Kepuasan Pelanggan. Dalam penelitian ini persamaan regresinya adalah sebagai berikut:

$$
\mathbf{Y}=\mathbf{a}+\mathbf{b X}+\mathbf{e}
$$

Dimana :

$$
\begin{array}{ll}
\mathrm{Y} & : \text { Kepuasan Pelanggan } \\
\mathrm{a} & : \text { Konstanta } \\
\mathrm{b} & : \text { Koefisien } \\
\mathrm{X} & \text { : Kualitas Produk } \\
\mathrm{e} & \text { : error }
\end{array}
$$

\section{Penguji Hipotesis Secara Parsial Dengan Uji t}

Uji statistik t atau uji parsial bertujuan untuk mengetahui seberapa jauh pengaruh variabel bebas secara individual dalam menjelaskan variabel terikat (Ghozali, 2009).

Uji t digunakan untuk menguji koefisien regresi secara parsial dari variabel independennya. Prosedur yang digunakan untuk melakukan uji t adalah:

1. Merumuskan hipotesis

$\mathrm{H} 1: \mathrm{b} 1: \mathrm{bn} \neq 0$, artinya bahwa terdapat pengaruh yang signifikan dari variabel independen terhadap variabel dependen secara parsial.

2. Menentukan tingkat signifikasi Hipotesis ini diuji dengan menggunakan tingkat signifikansi sebesar $\alpha=0,05$

3. Menentukan kriteria pengujian hipotesis penelitian

- Hipotesis diterima jika $t_{\text {signifikan }}<0,005$

- Hipotesis ditolak jika $t_{\text {signifikan }}>0,005$

\section{HASIL PENELITIAN DAN PEMBAHASAN}

\section{Hasil Penelitian}

Uji Validitas

Tabel 2. Hasil Uji Validitas

\begin{tabular}{lccc}
\hline Variabel & Pernyataan & Sig & Status \\
\hline Kualitas Produk $\left(\mathrm{X}_{1}\right)$ & $\mathrm{X}_{1.1}$ & 0,000 & Valid \\
& $\mathrm{X}_{1.2}$ & 0,000 & Valid \\
& $\mathrm{X}_{1.3}$ & 0,000 & Valid \\
& $\mathrm{X}_{1.4}$ & 0,000 & Valid \\
Kepuasan Pelanggan $(\mathrm{Y})$ & $\mathrm{Y}_{1.1}$ & 0,000 & Valid \\
& $\mathrm{Y}_{1.2}$ & 0,000 & Valid \\
& $\mathrm{Y}_{1.3}$ & 0,000 & Valid \\
& $\mathrm{Y}_{1.4}$ & 0,000 & Valid \\
\hline
\end{tabular}

Sumber : Olah data SPSS 20, 2017 
Tabel 1 dapat dilihat bahwa nilai signifikan untuk setiap pernyataan adalah < alpha yaitu 0,05 maka dapat disimpulkan bahwa setiap pernyataan dikatakan valid.

Uji Reliabilitas

Tabel 3. Hasil Uji Reliabilitas

\begin{tabular}{lccl}
\hline Variabel & Pernyataan & Cronbach Alpha & Status \\
\hline Kualitas Produk $\left(\mathrm{X}_{1}\right)$ & $\mathrm{X}_{1.1}$ & 0,728 & Reliabel \\
& $\mathrm{X}_{1.2}$ & & Reliabel \\
& $\mathrm{X}_{1.3}$ & & Reliabel \\
& $\mathrm{X}_{1.4}$ & & Reliabel \\
Kepuasan Pelanggan (Y) & $\mathrm{Y}_{1.1}$ & 0,795 & Reliabel \\
& $\mathrm{Y}_{1.2}$ & & Reliabel \\
& $\mathrm{Y}_{1.3}$ & & Reliabel \\
& $\mathrm{Y}_{1.4}$ & & Reliabel \\
\hline
\end{tabular}

Sumber : Olah data SPSS 20, 2017

Nilai alpha cronbach untuk setiap pernyataan > 0,6 maka dapat disimpulkan bahwa setiap pernyataan dikatakan reliable.

Analisis Regresi Linear Sederana

Tabel 4. Regresi Linear Sederana

\begin{tabular}{|c|c|c|}
\hline \multirow[t]{2}{*}{ Model } & \multicolumn{2}{|c|}{$\begin{array}{c}\text { Unstandardized } \\
\text { Coefficients }\end{array}$} \\
\hline & B & Std. Error \\
\hline 1 (Constant) & 8.926 & 1.525 \\
\hline Kualitas Produk & .425 & .092 \\
\hline
\end{tabular}

Sumber : Olah data SPSS 20, 2017

Model regresi $\mathrm{Y}=8,926+0,425 \mathrm{X}$ menggambarkan bahwa variabel bebas (independen) Kualitas Produk (X) dalam model regresi tersebut dapat dinyatakan jika satu variabel independen berubah sebesar 1 (satu) dan lainnya konstan, maka perubahan variabel terikat (dependen) Kepuasan Pelanggan (Y) adalah sebesar nilai koefisien (b) dari nilai variabel independen tersebut. Konstanta $(\alpha)$ sebesar 8,926 memberikan pengertian bahwa jika Kualitas Produk(X) sama tidak mengalami perubahan atau sama dengan nol (0) maka besarnya Kepuasan Konsumen (Y) sebesar 8,926 satuan. Jika nilai b yang merupakan koefisien regresi dari Kualitas Produk (X) sebesar 0.425 yang artinya mempunyai pengaruh positif terhadap variabel dependen (Y) mempunyai arti bahwa jika variabel Kualitas Produk (X) bertambah 1 satuan, maka Kepuasan Pelanggan (Y) akan mengalami Kenaikkan sebesar 0.425 satuan dengan asumsi variabel lain tetap atau konstan.

\section{Pengujian Hipotesis}

Perumusan hipotesis yang diuji dengan tingkat signifikansi yang digunakan dalam penelitian ini sebesar $5 \%$ atau $\alpha=0,05$ maka hasil pengujian hipotesis tersebut adalah sebagai berikut:

Uji t

Uji t digunakan untuk menguji signifikansi pengaruh variabel independen terhadap variabel dependen dalam model regresi yang sudah dihasilkan. Maka digunakan uji t untuk menguji masing-masing variabel independen terhadap variabel dependen. 
Tabel 5. Uji t

\begin{tabular}{llcc}
\hline Model & & $\mathbf{t}$ & Sig. \\
\hline 1 & (Constant) & 5.853 & .000 \\
& Kualitas Produk & 4.626 & .000 \\
\hline
\end{tabular}

Sumber : Olah data SPSS 20, 2017

Dari hasil uji t pada tabel diatas dapat dilihat bahwa Kualitas Produk $\left(X_{2}\right)$ signifikansi p-value $=0,000<0,05$, maka dapat disimpulkan bahwa $\mathrm{H}_{\mathrm{a}}$ diterima dan menolak $\mathrm{H}_{0}$ atau Kualitas Produk (X) berpengaruh signifikan terhadap Kepuasan Pelanggan (Y).

\section{Pembahasan}

Produk meupakan peruntukkan bagi pemuasan akan kebutuhan dan keinginan dari konsumen. Produsen harus memperhatikan secara hati - hati kebijakan akan produknya. Kualitas produk adalah karakteristik produk atau jasa yang bergantung pada kemampuannya untuk memuaskan kebutuhan yang dinyatakan atau tersirat. Hasil penelitian menunjukkan bahwa Kualitas Produk berpengaruh positif signifikan terhadap Kepuasan pelanggan Kopi Box Wanea Manado. Semakin tinggi Kualitas Produk yang ditawarkan maka akan semakin tinggi pula kepuasan pelanggan. Hal tersebut diakibatkan oleh karena produk yang dibuat merupakan hand made serta menggunakan alat-alat khusus pembuat kopi serta pengololaan serta adanya keunngulan produk yang diciptakan sendiri yang berbeda dari produk-produk pesaing. Hasil penelitian ini didukung oleh penelitian Widoyo dan Semuel (2014) yang menemukan bahwa Kualitas Produk berpengaruh signifikan terhadap Kepuasan Pelanggan.

\section{PENUTUP}

\section{Kesimpulan}

Dari hasil penelitian dan pembahasan di atas, maka dapat ditarik kesimpulan bahwa Kualitas Produk berpengaruh signifikan terhadap Kepuasan Pelanggan Di Kopi Box Wanea Manado

\section{Saran}

Berdasarkan hasil penelitian dan pembahasan di atas, maka penulis memberi saran sebagai berikut :

1. Mengingat Kualitas Produk memiliki pengaruh positif yang signifikan serta memberikan kontribusi yang cukup besar terhadap Kepuasan Pelanggan Di Kopi Box Wanea Manado. Maka pihak Owner harus memperhatikan faktor Kualitas Produk.

2. Penelitian ini hanya terbatas pada pengaruh kualitas produk terhadap kepuasan pelanggan, kiranya pada penelitian selanjutnya memasukkan variable lain.

\section{DAFTAR PUSTAKA}

Ghozali, Imam, 2009. Aplikasi Analisis Multivariate Dengan Program SPSS, Edisi Keempat, Penerbit Universitas Diponegoro.

Kotler, Philip dan Armstrong, Gary. 2012. Principles of Marketing. New Jersey: Prentice Hall.

Lovelock, Christopher, and Jochen Wirtz. 2011. Service Marketing, People, Technology,Strategy. New Jersey: Prentice Hall Upper Sadle River.

Widjoyo dan Semuel. 2014. Pengaruh Kualitas Layanan Dan Kualitas Produk Terhadap Kepuasan Pelanggan Dan Loyalitas Konsumen Restoran Happy Garden Surabaya, Jurnal Manajemen Pemasaran, Vol 2, No 1. Diakses bulan Desember 2016.

Swastha dan Handoko. 2012. Manajemen Pemasaran Analisis Perilaku Konsumen. Edisi Pertama. BPFE, Yogyakarta.

Sugiyono. 2012. Metode Penelitian Kuantitatif Kualitatif dan R\&D. Bandung: Alfabeta. 